\title{
PENDEKATAN PSIKOLOGI TERHADAP BUDIDAYATANAMAN LADA RAMAH LINGKUNGAN BERBASIS TEKNOLOGI BIO FOB
}

\author{
YohanesBerkhmas Mulyadi, Warkintin, Suryameng \\ STKIP Persada Khatulistiwa \\ yostellano@gmail.com,warkintin1984@yahoo.co.id
}

\begin{abstract}
Villagers of Riam Panjang have farmers, have extensive farmland, are rich in organic waste and have good climate such as good rainfall. The problem is that people are less concerned about agricultural land. The cause is a psychological thing such as perspective, mental, interest, attitude, self concept and community motivation in managing agriculture is still lacking. The method of execution in community service is counseling, with the result that the community is beginning to realize its potential, positive self-concept, intention and willingness to dare to start and believe that everything will succeed despite long process. This activity was conducted in Riam Panjang Village, Kayan Hulu Subdistrict, Sintang Regency, West Kalimantan

Keywords: Psychological Approach, Bio-FOB Technology
\end{abstract}

\begin{abstract}
Abstrak: Masyarakat desa Riam Panjang bermayoritas petani, memiliki lahan pertanian yang luas, kaya akan sampah organik dan memiliki iklim yang baik seperti curah hujan bagus. Masalah yang ditemukan adalah masyarakat kurang perhatian terhadap lahan pertanian. Penyebabnya adalah hal psikologisseperti cara pandang, mental, minat, sikap, konsep diri dan motivasi masyarakat dalam mengelolah pertanian masih kurang. Metode pelaksanaan dalam pengabdian kepada masyarakat adalah penyuluhan, dengan hasilnya adalah masyarakat mulai menyadari akan potensi yang dimiliki, konsep diri positif, niat dan keinginan untuk berani memulai dan yakin bahwa semuanya akan berhasil meskipun dilalui proses yang panjang. Kegiatan ini dilakukan di Desa Riam Panjang Kecamatan Kayan Hulu Kabupaten Sintang Kalimantan Barat

Kata kunci: Pendekatan psikologis, Teknologi Bio-FOB.
\end{abstract}

\section{PENDAHULUAN}

\section{a. Latar Belakang}

Sektor pertanian merupakan salah satu tulang punggung dalam pembangunan perekonomian nasional. Selain mampu menyerap tenaga kerja, juga berperan dalam pembentukan PDB (Produk Domestik Bruto), penerimaan devisa, penyediaan pangan, pengentasan kemiskinan, perbaikan pendapatan masyarakat, bahkan pembentuk budaya bangsa dan penyeimbang ekosistem.

Salah satu hal penting dalam sektor pertanian adalah sektor pangan.
Ketersediaan pangan menjadi sangat penting seiring dengan tingkat pertumbuhan masyarakat Indonesia saat ini. Berdasarkan sensus penduduk tahun 2015, jumlah penduduk Indonesia sudah mencapai 257,9 juta jiwa. Jumlah ini menuntut ketersediaan dan ketahanan pangan yang besar untuk dipenuhi. Oleh karena itu, dalam mengatasi persoalan pangan ini, investasi sektor pangan perlu untuk ditingkatkan.

Kepala Badan Pusat Statistik (BPS) Suharyanto mencatat 39, 68 juta penduduk Indonesia bekerja di sektor pertanian, atau $31,86 \%$ dari total 
penduduk. Sementara di sektor lain seperti sektor perdagangan yakni sebanyak 29,11 juta orang yang bekerja atau berhasil menyerap 23,37 \% dari total tenaga kerja yang ada. Selanjutnya jasa kemasyarakatan 20,95 juta orang atau menyerap tenaga kerja sebesar 16, $82 \%$, disusul sektor industri $13,31 \%$, konstruksi $5,75 \%$, transportasi $4,57 \%$, keuangan 2,88\%, pertambangan $1,1 \%$ dan listrik, air, gas sebesar 0,34\%. (www.kompas post,24 Maret 2017)

Suharyanto selanjutnya dalam data menunjukkan bahwa pada triwulan II tahun 2017, sektor pertanian memberi kontribusi positif untuk pertumbuhan ekonomi Indonesia. Berdasarkan data itu, terlihat bahwa besaran Produk Domestik Bruto (PDB) mencapai Rp $3.366,8$ triliun.Kemudian, bila dilihat dari sisi produksi, sektor pertanian merupakan sektor kedua yang paling berpengaruh terhadap pertumbuhan ekonomi, setelah industri pengolahan, dan posisinya masih di atas sektor perdagangan dan konstruksi. Untuk triwulan II tahun 2017 ini, sektor pertanian dalam arti luas menyumbang sebanyak 13,92 persen, sementara pada triwulan-I tahun 2017 kontribusinya13,59 \%.Pertumbuhan di sektor pertanian ini tidak lepas dari berbagai program pemerintah guna mewujudkan swasembada sejumlah komoditas pertanian strategis dengan menetapkan visi Indonesia menjadi Lumbung pangan Dunia pada 2045.

Menteri Pertanian, Amran Sulaiman menyatakan Kementerian Pertanian bertekad untuk mengembalikan kejayaan kopi, lada, panili dan rempah serta komoditas perkebunan lainnya dan subsektor hortikultura. Untuk itu, Kementerian Pertanian menyiapkan anggaran sebesar $\mathrm{Rp}$ 5,5 triliun untuk dua subsektor tersebut dan diharapkan setiap kabupaten dapat meningkatkan produktivitas pertanian melalui budidaya pelbagai jenis pertanian. (www.kompas post,24 Maret 2017)

Salah satu komoditas ekspor yang banyak manfaatnya adalah lada. Lada atau merica merupakan tanaman yang mampu tumbuh subur di Indonesia dan banyak digunakan sebagai bumbu atau rempah - rempah, bisa dikatakan hampir semua masakan menggunakan bahan yang satu ini. Masyarakat Indonesia sebagian besar belum mengetahui bentuk pohon lada bahkan belum mengetahui cara menanam lada khususnya menanam tananan lada ramah lingkungan berbasis teknologi Bio FOB - Mengingat lada merupakan salah satu rempah yang banyak sekali digunakan dan kebutuhan akan lada semakin meningkat serta harga lada atau merica 


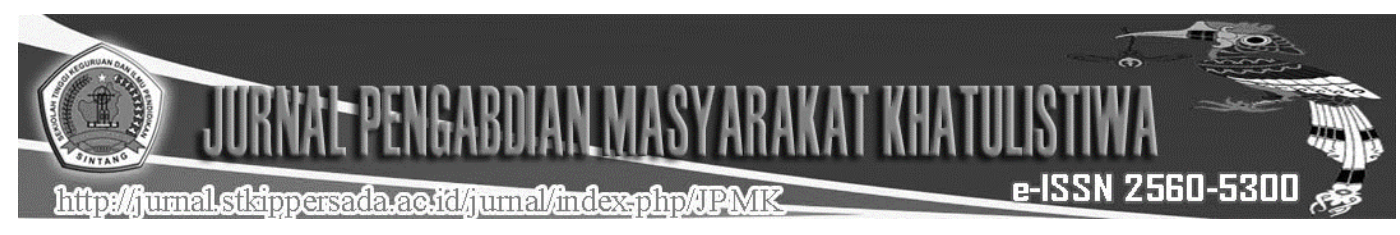

yang bisa dibilang fantastis hingga mencapai Rp. 115.000 - Rp 170.000 per $\mathrm{kg}$, maka budidaya lada bisa dijadikan sebagai ladang bisnis yang menguntungkan.( www.kapuas post, 30 Agustus 2017).

Paradigma modern dalam psikologi pertanian adalah membentuk perilaku petani yang rajin, bertanggungjawab, memiliki motivasi, minat, kecerdasan dalam mengelolah areal pertanian. Perilaku petani yang demikian adalah tanda mencintai eksistensi dirinya sebagai pribadi yang mau berkembang, (Sumanto, 2014). Dalam konteks ini, pendekatan psikologi terhadap budidaya tanaman lada ramah lingkungan berbasis teknologi Bio FOB adalah menggali potensi petani dan mengarahkan petani sebagai pribadi yang memiliki cara pandang atau kecerdasan, minat, sikap, motivasi, perasaan dan karakteristik lainnya yang dapat mengembangkan dan membudidayakan tanaman lada. Pengembangan pendekatan psikologi pertanian berkaitan erat dengan proses pembelajaran petani, diantaranya (1) dalam hal pencapaian kemampuan petani untuk melakukan sesuatu dalam berbagai konteks kebutuhan, (2) dalam hal proses pembentukan konsep diri positif pada petani, (3) dalam hal pengembangan potensi,cara pandang, mental, sikap, minat dan motivasi petani, (Abdul, 2006)

Informasi dari beberapa tokoh masyarakat dan tokoh adat Desa Riam Panjang menyatakan bahwa desa Riam Panjang memiliki lahan pertanian yang sangat luas tetapi belum bahkan tidak dikelolah untuk menjadi lahan pertanian potensial. Realita percepatan pembangunan saat ini dimana dibuka akses jalan ke desa-desa,kendaraan umum memberanikan diri masuk ke desa Riam Panjang pada musim kering, membuat petani tergerak hati dan terbuka pikiran untuk mengelolah lahan pertanian dengan serius dan tekun. Namun masih banyak masyarakat tani yang memiliki cara pandang dan mental tidak peduli dengan kondisi real tersebut atau masih terkekang dengan paradigma enjoy life artinya menikmati hidup apa adanya tanpa kerja keras.

Cara pandang dan mental masyarakat seperti ini akan mempengaruhi masyarakat tani lainnya yang menginginkan lahan pertanian dikelolah secara baik dengan membudidayakan pelbagai macam tanaman termasuk tanaman lada yang disinyalir dapat memberikan kontribusi bagi pendapatan keluarga. Menyikapi dan menanggapi informasi tersebut, maka dicoba mengadakan pendekatan psikologis pertanian terhadap petani 


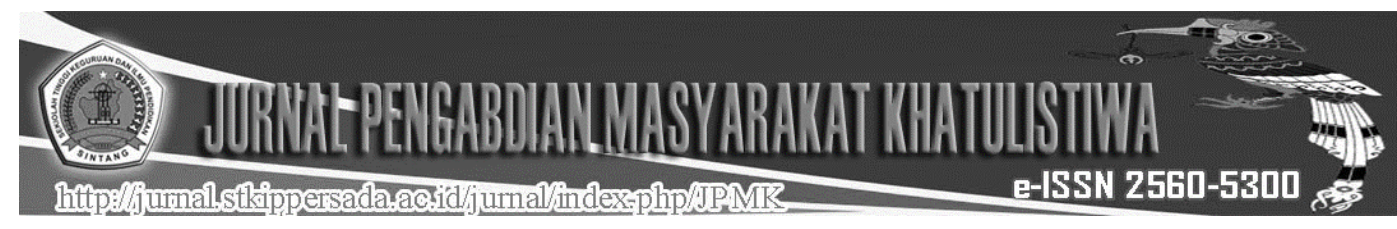

agar terbuka wawasan, cara pandang, mental, sikap,minat dan kemauan untuk membudidayakan pelbagai macam tanaman, khususnya membudidayakan tanaman lada ramah lingkungan berbasis tekonologi Bio FOB, (www.kapuas post, 10 April 2016).

Menurut Setiawan (2014) budi daya tanaman lada ramah lingkungan merupakan proses kegiatan budidaya tanaman lada yang memperhatikan kaidah-kaidah ramah lingkungan, meminimalisir penggunaan bahan-bahan kimia, dan tidak merusak lingkungan. Teknologi Bio-FOB adalah inovasi baru dalam budidaya pertanian dengan memanfaatkan mikroorganisme dan ekstrak tanaman. Teknologi ini berorientasi organic farming (pertanian organik) dan ramah lingkungan. Mikroorganisme yang digunakan dalam teknologi Bio-FOB bisa meningkatkan ketahanan, kualitas dan produktivitas tanaman.

Spesifikasi komponen teknologi BioFOB antara lain

1. Bibit Bio-FOB diproduksi dengan menggunakan fusarium oxysporum non patogenik (FO,NP). Mikroba ini berfungsi untuk menginduksi system ketahanan tanaman dan merangsang perakaran yang menghasilkan hormon pertumbuhan pada perakaran.
2. Bio-TRIBA yaitu formula dalam bentuk cair mengandung mikroorganisme pantotkenticus dan lactae. Larutan ini dapat digunakan sebagai biodekomposer limbah organik dan biofungisida untuk pengendalian pathogen tanaman serta dapat dicampur dengan pupuk organik.

3. Organo-TRIBA yakni kompos organik yang diproses dari limbah organik dengan menggunakan BioTRIBA sebagai biodekomposer yang mengandungbeberapa mikroorganisme seperti Bacillus, Trichoderma, Flourescens dan Penicillium. Ekstra kompos organo-TRIBA ini dapat berfungsi sebagai pestisida terhadap hama, (Tabloid Sinar Tani Edisi Februari, 2010).

Substansinya menurut Maria Bintang (2010) mengutarakan kegiatan budidaya tanaman lada ramah lingkungan berbasis tekonologi Bio FOB artinya (1) membudidayakan tananam lada dengan menggunakan bahan organik, (Organo TRIBA) (2) menggunakan bibit sehat dan tidak dikenani penyakit (bibit Bio FOB), (3) menggunakan pestisida organik atau agensi hayati untuk pengendalian hama penyakit (Siori SPO, Mitol 20 EC, Bio TRIBA BT3)

Permasalahan masyarakat tani Riam Panjang sebagai mitra dapat 
dilihat dari berbagai aspek seperti aspek sosial, budaya, religi, kesehatan, mutu layanan dan permasalahan khusus yang menjadi persoalan prioritas mitra yaitu aspek psikologis masyarakat.Aspek sosial yaituhidup sosial masyarakat sudah bagus namun realita sosial terhadap alam masih kurang perhatian karena membiarkan lahan pertanian tanpa diolah ataupun diolah hanya dengan menanam ubi, padi, tanpa ditanami tanaman perdagangan.

Aspek budaya artinya cara atau pola hidup masyarakat yang mencari sesuatu bersifat instan, kurang serius dan tekun mengolah lahan pertanian sebagai sumber pendapatan petani. Aspek religi artinya masyarakat memiliki nilai religi yang kuat, masih ada yang menganut kepercayaan tradisionaldan melakukan hal-hal tersebut sebagai cerminan dari religiusitasnya. Aspek kesehatan artinya kondisi umum kesehatan masyarakat Riam Panjang bisa disebut baik.Masyarakat mulai menjaga kebersihan, lingkungan dan kesehatan diri serta keluarganya.Kehadiran petugas kesehatan pun ditanggapi baik oleh masyarakat. Hal ini dapat diketahui kalau ada yang sakit, dapat berobat secara medis, meskipun ada juga masyarakat yang berobat kepada orangorang yang dianggap dapat menyembuhkan.
Berdasarkan uraian tersebut, maka dalam program pengabdian kepada masyarakat ini, dilakukan kegiatan penyuluhan tentang pendekatan psikologis bagi masyarakat Riam Panjang agar muncul animo tani dengan membudidayakan tanaman lada ramah lingkungan berbasis teknologi Bio FOB. Adapun judul kegiatan pengabdian kepada masyarakat ini adalah "Pendekatan Psikologis terhadap Budidaya Tanaman Lada Ramah Lingkungan Berbasis Teknologi Bio FOB”.

\section{b. Rumusan Masalah}

Desa Riam Panjang Kecamatan Kayan Hulu Kabupaten Sintang merupakan salah satu desa yang penduduknya bermayoritas petani, memiliki lahan pertanian yang luas, kaya akan sampah organik dan memiliki iklim yang baik seperti curah hujan bagus, memiliki sinar matahari, suhu udara kadang 200C-34 OC dengan kelembaban udara sekitar 50-100 \% bagus dan memiliki tanah yang subur, tidak terlalu keringpH tanah 5,5-7,0, Warna tanah merah sampai merah kuning seperti Podsolik, Lateritic, Latosol dan Utisol, Kandungan humus tanah sedalam 1-2,5 m.(BPS.Sintang, 2014) 


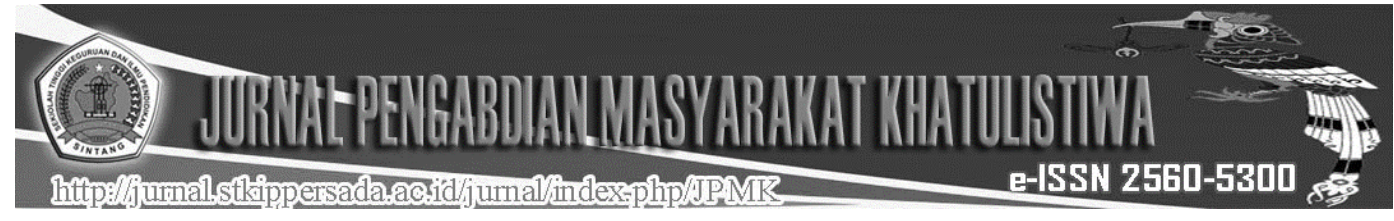

Kondisi daerah ini sejatinya memotivisir masyarakat untuk mengelolah tanah, membudidayakan pelbagai jenis tanaman, namun bagi masyarakat Riam Panjang, hal tersebut kurang menjadi acuan untuk mengelolah areal pertanian secara serius.

Aspek psikologis yang menjadi persoalan prioritas mitra seperti cara pandang, mental, sikap, keinginan,minat, konsep diri dan motivasi mereka dalam mengelolahpertanian masih kurang dan masyarakat lebih memilih pekerjaan lain yang berkontribusi bagi pendapatan keluarga tetapi memberi efek atau resiko nyawanya tinggi yaitu bekerja di pertambangan emas ilegal.Realita inilah yang mendorong untuk segera melakukan pendekatan psikologis terhadap masyarakat tani Riam Panjang agar muncul animo tani dengan membudidayakan tanaman lada ramah lingkungan berbasis teknologi Bio FOB.

Berdasarkan analisis terhadap latar belakang dan kajian terhadap gambaran umum dan situasi, maka masalah yang diangkat dalam kegiatan pengabdian kepada masyarakat ini dan menjadi prioritas mitra yang bersifat konkret serta benar-benar sesuai dengan kebutuhan mitra,diantaranya
1. Bagaimana pencapaian kemampuan petani untuk melakukan sesuatu dalam berbagai konteks kebutuhan

2.Bagaimana proses pembentukan konsep diri positif pada petani

3.Bagaimana cara mengembangkan potensi, cara pandang, mental,sikap, minat dan motivasi petani dalam membudidayakan tanaman pertanian khususnya budidaya tanaman lada ramah lingkungan berbasis teknologi Bio FOB.

\section{c. Tujuan Pengabdian}

Tujuan pengabdian kepada masyarakat dalam kegiatan ini adalah

1. Memotivisir masyarakat tani agar mampu melakukan sesuatu dalam berbagai konteks kebutuhan.

2. Membentuk konsep diri positif pada petani.

3.Mengembangkanpotensi, cara pandang, mental,sikap, minat, dan motivasi petani agar tergerak hati dan terbuka pikiran, ada semangat dalam membudidayakan tanaman pertanian khususnya budidaya tanaman lada ramah lingkungan berbasis teknologi Bio FOB. Budidaya tanaman lada saat ini adalah peluang usaha yang dapat berkontribusi bagi pengembangan perekonomian masyarakat Desa Riam Panjang sekaligus memberikan pendapatan keluarga yang bagus.

SOLUSI DAN LUARAN 


\section{a. Sasaran Program}

Sasaran Program dalam kegiatan pengabdian kepada masyarakat ini adalah masyarakat Desa Riam Panjang Kecamatan Kayan Hulu Kabupaten Sintang Kalimantan Barat

\section{b. Solusi Penyelesaian Masalah}

Berdasarkan permasalahan mitra yang telah dipaparkan diatas maka solusi yang ditawarkan pada pelaksanaan pengabdian kepada masyarakat (PkM) yaitu

1. Masyarakat diberikan pemahaman tentang pencapaian kemampuan petani untuk melakukan sesuatu dalam berbagai konteks kebutuhan

2. Masyarakat diberikan pemahaman tentang proses pembentukan konsep diri positif

3. Masyarakat diberikan pemahaman tentang cara mengembangkan potensi, cara pandang, mental,sikap, minat, kemauan dan motivasi petani dalam mengelolah budidaya tanaman lada ramah lingkungan berbasis teknologi Bio FOB.

\section{c. Target Luaran}

Target luaran yang diharapkan pada pengabdian kepada masyarakat(PkM) antara lain :

1. Masyarakat tani desa Riam Panjang dapat memahami tentang a) Nilai-nilai kemampuan dasar petani yang direfleksikan dalam kebiasaan berpikir dan bertindak, b) Kepedulian petani terhadap daerah pertanian ,c) Pentingnya penggunaan teknologi Bio FOB dalam mengurangi serangan hama penyakit tanaman.

2. Masyarakat dapat memahami makna a) Konsep diri positif pada petani,b) Model pembentukan diri petani yang cerdas, mandiri dan berkualitas, c) Pentingnya sikap moral, etika dan peduli bagi seorang petani terhadap lahan pertanian.

3. Masyarakat dapat mengembangkan a)potensi, cara pandang, mental, minat,sikap, kemauan, dan motivasi petani dalam mengelolah tanaman pertanian khususnya tanaman lada, b) Cara budidaya tanaman lada ramah lingkungan c) Manfaat teknologi Bio FOB bagi tanaman lada, d)Pendapatan bagi masyarakat pengelolah tanaman lada.

\section{METODE PELAKSANAAN}

\section{a. Metode Pelaksanaan}

Metode pelaksanaan dalam kegiatan pengabdian kepada masyarakat ini dilakukan dengan carapenyuluhan atau

memberikaninformasi/ceramah,tentang pendekatan psikologis bagi masyarakat tani dalam membudidayakan tanaman 
lada ramah lingkungan berbasis tekonologi Bio FOB.

b. Pelaksanaan

Kegiatan

\section{Pengabdian}

Kegiatan pengabdian kepada masyarakat dilaksanakan di Desa Riam Panjang Kecamatan Kayan Hulu Kabupaten Sintang Kalimantan Barat pada tanggal 08Desember 2017, dimulai pukul 08.00 - 15.00 Wiba, bertempat di gedung SMPN 7 SATAP Kayan Hulu

\section{HASIL DAN PEMBAHASAN}

\section{a. Hasil Kegiatan}

Berdasarkan permasalahan mitra yang telah dipaparkan di atas dan penyuluhan yang telah dilakukan oleh pemateri maka beberapa temuan dan hasilkegiatan pengabdian kepada masyarakat $(\mathrm{PkM})$ yaitu

1. Masyarakatantusias mengikuti kegiatan PkM ini dan menyadari akan potensi yang dimiliki dan berupaya membangun potensi itu dengan segera melakukan sesuatu dalam berbagai konteks kebutuhan.

2. Masyarakatsudah memahami akan konsep diri positif bahwa semakin mereka berpikir maju dan mengaktualisasikan apa yang dipikirkan itu secara baik maka akan menghasilkan kepercayaan diri, kekuatan diri dan keyakinan bahwa usaha mengelolah lahan pertanian akan berhasil bila dilaksanakan dengan kesabaran, kerja keras, pengorbanan, keuletan, tekun dan doa

3. Masyarakatsudah memahami potensi, cara pandang, mental,sikap, minat dan motivasi petani dalam mengelolah budidaya tanaman lada ramah lingkungan berbasis teknologi Bio FOB.Hal ini ditemukan dari niat dan keinginan untuk berani memulai dan yakin bahwa semuanya akan berhasil meskipun dilalui proses yang panjang.

Foto kegiatan

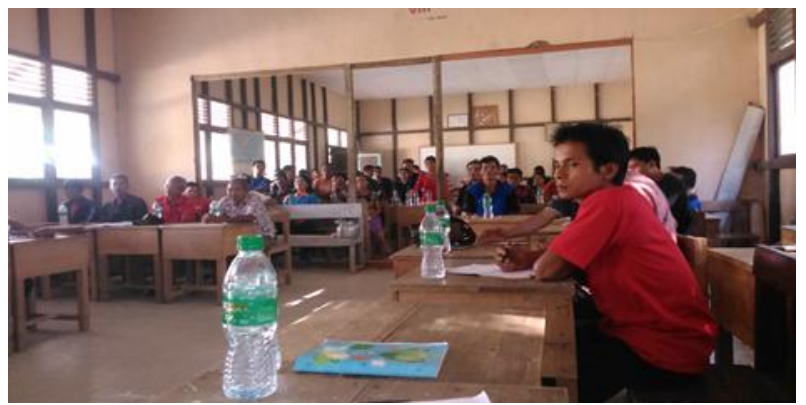

b. Pembahasan

KegiatanPengabdian Kepada Masyarakat(PkM) di desa Riam Panjang Kecamatan Kayan Hulu disampaikan di media massa melalui jurnal sebagai luaran yang dicapai supaya masyarakat umum dapat mengetahui pendekatan psikologis terhadap budidaya tanaman lada ramah lingkungan berbasis teknologi Bio FOB. Adapun luaran yang dicapai pada kegiatan Pengabdian Kepada Masyarakat (PkM) ini adalah 
1. Petani mampumelakukan sesuatu dalam berbagai konteks kebutuhan. Hal ini diketahui dari antusiasme dan mulai kepedulian terhadap lahan pertanian

2. Konsep diri positif petani mulai terlihat dari pemahaman terhadap kelebihan dan kekurangan yang dialami. Konsep diri adalah cara pandang terhadap diri sebagai petani yang memiliki potensi dalam mengelolah lahan pertanian

3.Petani memiliki respek terhadap budidayatanaman lada ramah lingkungan berbasis teknologi Bio FOB. Selain itu harga jual lada setiap tahun semakin meningkat sehingga dapat memotivisir petani untuk serius membudidayakan tanaman lada.

\section{KESIMPULAN DAN SARAN}

\section{a. Kesimpulan}

Penduduk desa Riam Panjang bermayoritas petani, memiliki lahan pertanian yang luas, kaya sampah organik dan memiliki iklim yang baik seperti curah hujan bagus, memiliki suhu udara kadang 200C-34 OC dengan kelembaban udara sekitar 50-100 \% bagus dan memiliki tanah yang subur, tidak terlalu keringpH tanah 5,57,0.Kondisi daerah ini sangat cocok untuk mengelolah tanah dan membudidayakan pelbagai jenis tanaman, termasuk tanaman
lada.Masyarakat kurang respek terhadap lahan pertanian yang luas dan potensial.Tanaman yang ditanam pun hanya padi, ubi-ubian.Kurang menanam tanaman perdagangan.

Aspek psikologis yang menjadi persoalan prioritas mitra seperticara pandang, mental, sikap, minat, konsep diri dan motivasi mereka dalam mengelolah pertanian masih kurang dan masyarakat lebih memilih pekerjaan lain yang berkontribusi bagi pendapatan keluarga tetapi beresiko tinggi yaitu bekerja di pertambangan emas ilegal.Pendekatan psikologis terhadap masyarakat Riam Panjangsebagai solusi alternatif agar muncul animo tani dalam mengelolah lahan pertanian khususnya membudidayakan tanaman lada ramah lingkungan berbasis teknologi Bio FOB. Hasil dari kegiatan $\mathrm{PkM}$ antara lainnya : 1. Masyarakatmulai menyadari akan potensi yang dimiliki dan berupaya membangun potensi itu dengan segera melakukan sesuatu dalam berbagai konteks kebutuhan.

2. Masyarakatsudah memahami akan konsep diri positif bahwa semakin mereka berpikir maju dan mengaktualisasikan apa yang dipikirkan itu secara baik maka akan menghasilkan kepercayaan diri,dan keyakinan bahwa usaha mengelolah lahan pertanian akan berhasil bila dilaksanakan dengankerja 


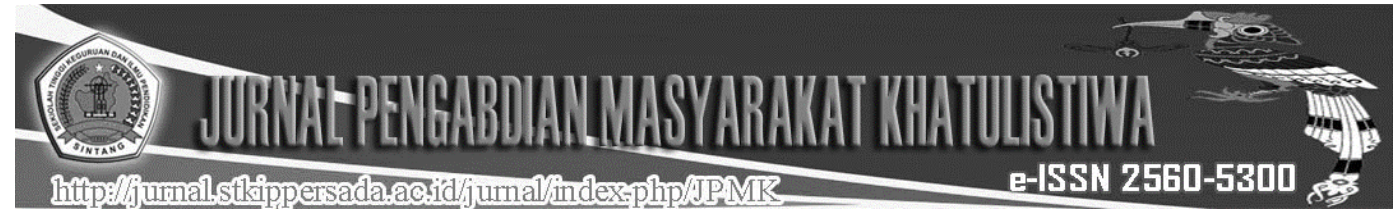

keras, pengorbanan, keuletan, tekun dan doa

3. Masyarakatsudah memahami potensi, cara pandang, mental,sikap, minat dan motivasi petani dalam mengelolah budidaya tanaman lada ramah lingkungan berbasis teknologi Bio FOB.

\section{b. Saran}

1. Bagi Masyarakat Riam Panjang

Masyarakat tani Riam Panjang untuk terus tergerak hati dan terbuka pikiran, memiliki motivasi dan paradigma modern bahwa mengelolah lahan pertanian dengan membudidayakan tanaman lada ramah lingkungan dengan teknologi Bio-FOB akan memberi pendapatan ekonomi yang sangat bagus. Harga jual Lada yang terus naik kiranya memotivisir petani untuk semangat menanamtanaman lada

\section{Bagi Pemerintah}

Pemerintah Desa dan Pemerintah Kabupaten serta pihak swasta perlu bekerjasama membangun daerah di sektor pertanian. Dukungan Pemerintah Kabupaten dalam hal meningkatkan ekonomi masyarakat dengan cara mengunjungi desa-desa, mendengar aspirasi dan keluhan masyarakat dan berupaya memberi solusi khususnya dalam hubungan dengan kondisi perekonomian masyarakat saat ini.
Pemerintah Kabupaten pun diharapkan membuka akses jalan ke desa-desa supaya transportasi darat lancar dan dengan sendirinya ekonomi masyarakat setempat akan berkembang

3. Bagi Pengabdi selanjutnya

Kegiatan pengabdian kepada masyarakat dalam hubungan dengan psikologi pertanian kiranya menjadi referensi bagi pengabdi lainuntuk terus meningkatkan semangat masyarakat dalam mengelolah lahan pertanian dengan menggunakan teknologi Bio FOB.

\section{REFERENSI}

Abdul.H2006. Psikologi Dalam Pendidikan. Bandung: Alfabeta

BPS Sintang. 2014.

Maria Bintang.2010.Biokimia Teknik Penelitian.Jakarta: Erlangga.

Setiawan, B.S, 2014Membuat Pupuk Kandang Secara Cepat.Jakarta: Swadaya

Sumanto, 2014.Psikologi Umum. Yogyakarta: CAPS

Tabloid Sinar Tani,Edisi Februari 2010.Bio-FOB Pertanian Organik

www.kapuas post.Pertanian Organik Ramah Lingkungan, Terbit: 30 Agustus 2017

www.kapuas post.Motivasi Petani dalam Mengembangkan Lahan Pertanian. Dinas Pertanian Kabupaten Sintang. 10 April 2016

www.kompas.com.Pertanian Beri 
Positif

TerhadapPertumbuhan Ekonomi

RI.Terbit24 Maret 2017 